\title{
Improving Soybean Production Using Light Supplementation at Field-Scale: A Case Study
}

\author{
Ernane M Lemes (Corresponding Author) \\ Institute of Agrarian Science (ICIAG), Federal University of Uberlândia (UFU), campus \\ Glória, Uberlândia, Brazil. Postal code: 38.410-337. \\ Email: ernanefito@gmail.com
}

Breno N R Azevedo

ICIAG, UFU, campus Glória, Uberlândia, Brazil. Postal code: 38.410-337.

Email: brenoagro.azevedo@gmail.com

Matheus F I Domiciano

ICIAG, UFU, campus Monte Carmelo, Brazil. Postal code: 38.500-000.

Email: matheusiida@hotmail.com

\begin{abstract}
Samuel L Andrade
Institute of Geografy (IG), UFU, campus Monte Carmelo, Brazil. Postal code: 38.500-000.

Email: samuelandrade@ufu.br
\end{abstract}

Received: June 19, 2021 Accepted: July 26, 2021 Published: July 29, 2021

doi:10.5296/jas.v9i3.18889

URL: https://doi.org/10.5296/jas.v9i3.18889

\begin{abstract}
In modern agriculture, there is a growing need for increasing crop efficiency while minimizing environmental impacts. The use of high-efficiency light supplementation to enhance plant development is limited for high-productive crops at field conditions (outdoor). This study evaluated the soybean plant's yield responses in an open commercial area (field scale) cultivated under conditions of artificial light supplementation. A commercial irrigated (pivot) area received an illumination system for light supplementation (LS) in its inner pivot
\end{abstract}


spans. About 40 hours of LS were applied to the plants during the soybean crop cycle. The area's outer pivot spans did not receive light supplementation (nLS). The internode number, the plant height, the pods per plant were evaluated weekly to compute the area under the progress curve (AUPC). The grain yield at harvest was also assessed. The AUPC of the internode number, plant height and pods per plant were positively affected by the LS treatment. The regular soybean cycle (nLS) is about 17 weeks; however, the LS harvest occurred three weeks later. Light supplementation increased soybean grain yield by $57.3 \%$ and profitability by $180 \%$ when compared to nLS. Although light supplementation at field scale poses a challenge, it is now affordable since sustainable field resistant technologies are now available. The present study is the first known report of light supplementation used to improve soybean crop production at field scale.

Keywords: Glycine max, light-emitting diode, crop yield, crop management, agriculture 4.0

\section{Introduction}

Modern agriculture has been continuously compelled to advance and to make use of sustainable technologies. Such technologies include genetic breeding tools, efficient-release fertilizers, soil management strategies, intelligent use of water and agrochemicals, internet of things, crop and weather monitoring, nanotechnology and integrated techniques of farm administration among others (Ali et al., 2018; Chowdhury et al., 2019; Leakey et al., 2019; Lowenberg-DeBoer \& Erickson 2019; Pandey et al., 2019; Saiz-Rubio \& Rovira-Más, 2020; Singh \& Singh, 2020; Devlet, 2021).

Crop producers also desire crop cultivars with the following traits: (i) optimum nutritional content for human consumption, (ii) high performance when compared to other cropping systems, and (iii) can withstand diverse environmental conditions (Roberts \& Mattoo, 2019). Other currently implemented technologies include genetically modified (GM) plants that beneficial to growers, consumers, and countries' economies (Raman, 2017) and bioactive compounds like plant growth regulators (Small \& Degenhardt, 2018; Harsimrat \& Kaur, 2020). Such plant growth regulators (e.g. plant hormones), when applied in small quantities, can alter plant processes from seed germination to plant senescence. Bioactive compounds can also enhance or stimulate natural plant development and the source-sink relationship of a plant's photoassimilates (Toungos, 2018).

In the past decades, the above mentioned technologies were all used to accelerate crop intensification. The utilization levels of these technologies in Latin America and Asia countries almost matched that of North America and Europe (Pellegrini \& Fernández, 2018). Additionally, a constantly growing human population and climatic changes (global warming) posed a challenge for all human activities, especially to crop production (Besada \& Sewankambo, 2010; IPCC, 2014; Tamiru \& Fekadu, 2019). There was also an increase in agrarian pressure on existing environmental resources (Balogh \& Jámbor, 2020). Therefore, there was an actual need for crop production intensification using advanced sustainable technological approaches.

Improving plant efficiency is a process used to sustainably increase the crop production 
potential (Orr et al., 2017; van Iersel, 2017; Nowicka et al., 2018; Kaiser et al., 2019; Batista-Silva et al., 2020; Singer et al., 2020). This can be done using different strategies including genetic techniques like the use of genetically modified organisms (Simkin et al., 2019), management of soil microbiota (Silva et al., 2021), or the addition of yield factors such as light (Goto, 2003; Gupta, 2017).

Gomez and Izzo's (2018) review illustrated the positive effects of light supplementation using light-emitting diode (LED) on plant metabolism and the negative impact of pest insects and diseases on crop production. Therefore, crop producers can optimize energy efficiency and plant productivity by increasing the canopy light capture efficiency and controlling the light output in response to environmental and physiological parameters using LEDs (Hemming, 2011; Bures et al., 2018).

Global food production relies on plant protein production for stock-farming and subsequent human consumption. The soybean is considered a strategic crop for plant protein production. Brazil is a leading soybean producer with an annual grain production of 124.8 million tons (Conab, 2020). Brazil's high soybean production results from a combination of factors such as the use genetically improved cultivars and advanced crop management technologies. Because sufficient amounts of food must be produced to meet the needs of an increasing population in a climate-changing world, newer techniques and advanced farm management strategies with minimal environmental impact must be implemented to increase crop production.

The objective of this study was to evaluate the soybean plant and its yield responses in a commercial area (field scale) where it was cultivated in conditions of artificial light supplementation.

\section{Method}

\subsection{Experimental Area and Soybean Cropping}

The experiment was implemented on a commercial farm in Monte Carmelo, Minas Gerais state, Brazil; located at $18^{\circ} 57^{\prime \prime} \mathrm{S}, 47^{\circ} 25^{\prime \prime} \mathrm{W}$, at $980 \mathrm{~m}$ above sea level that used irrigation (pivot system). The region's most common and representative biome is the Cerrado (Savannah-like biome). The climate of the region is $\mathrm{Cw}$ (humid subtropical with dry winter) (Beck et al., 2018).

The soil's physical analysis (0-0.4 m) indicated 450, 100, and $450 \mathrm{~g} \mathrm{~kg}^{-1}$ of sand, silt, and clay, respectively. The soil chemical characteristics up to a depth of $0.4 \mathrm{~m}$ are presented in Table 1 .

Table 1. Soil chemical characterization at 0-0.2 and 0.2-0.4 $\mathrm{m}$ soil layer.

\begin{tabular}{|c|c|c|c|c|c|c|c|c|c|}
\hline $\mathrm{pH} \mathrm{H} \mathrm{H}_{2} \mathrm{O}$ & $\mathrm{Ca}$ & $\mathrm{Mg}$ & $\mathrm{Al}$ & $\mathrm{H}+\mathrm{Al}$ & CEC & $\mathrm{V}$ & $P$ & K & S.O.M \\
\hline $1-2.5$ & ---- & ----- & $\mathrm{ol}_{c} \mathrm{C}$ & ------ & ----- & $\%$ & -----m & -3 & $\mathrm{~g} \mathrm{~kg}^{-1}$ \\
\hline 6.9 & 6.03 & 2.87 & 0 & 1.26 & 10.44 & 88 & 188 & 96 & 2.9 \\
\hline
\end{tabular}




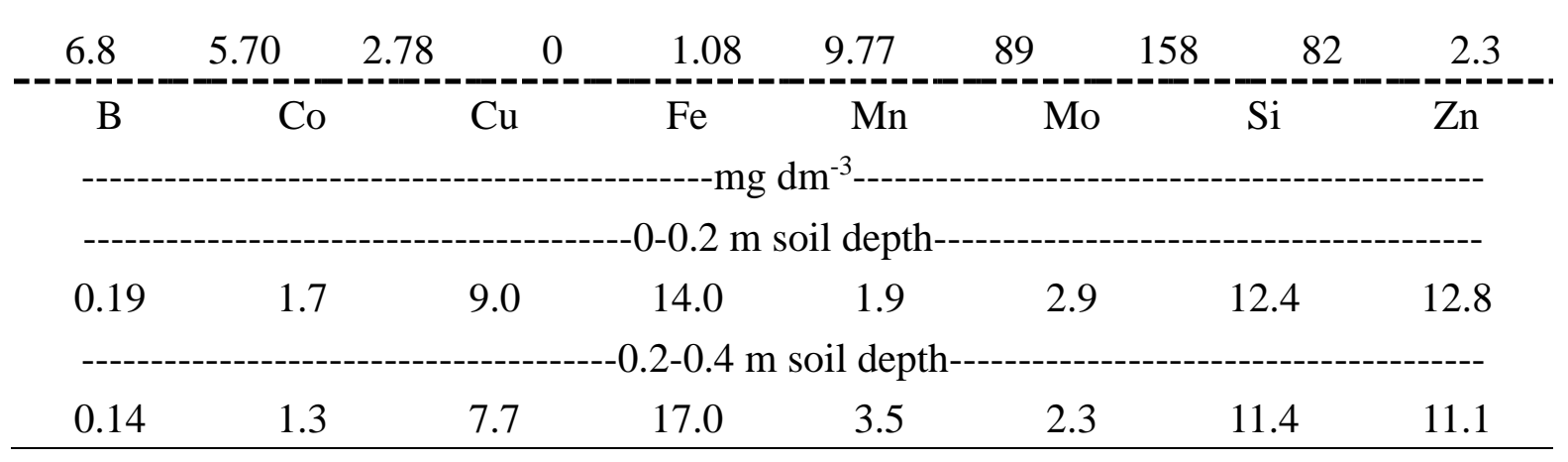

$\mathrm{CEC}=$ cation exchange capacity at $\mathrm{pH} 7 ; \mathrm{V}=$ saturation of bases; S.O.M. = soil organic matter. Methodologies source: Embrapa (2017).

Despite having a large proportion of clay in the soil and a high natural fertility, 3,000 $\mathrm{kg} \mathrm{ha}^{-1}$ of soil remineralizer (rock powdery) (FMX® Tratto. Aparecida de Goiânia, Brazil) was applied to the entire experimental area 30 days before sowing the soybean; $400 \mathrm{~kg} \mathrm{ha}^{-1}$ of organomineral 06-30-05 (\% of N, $\mathrm{P}_{2} \mathrm{O}_{5}, \mathrm{~K}_{2} \mathrm{O}$ ) (Valoriza Agro Ltda. Patos de Minas, Brazil) and $150 \mathrm{~kg}$ of $\mathrm{KCl}$ was applied at the time of sowing, and $2 \mathrm{~L} \mathrm{ha}^{-1}$ of $\mathrm{Mn}$ was sprayed on the plant canopy 40 days after crop emergence.

The soybean cultivar evaluated in this experiment was the Desafio 8473 RSF (Brasmax ${ }^{\circledR}$ GDM. Cambé, Brazil) - indeterminate growth, maturity group 7.4. In October 2019, fourteen seeds were sown per square meter (280,000 plants per hectare); the plants were then harvested in February 2020. The daily average air temperature during the experimental period ranged from 24 to $34{ }^{\circ} \mathrm{C}$ (weatherspark.com).

At the experimental area, insect pests, plant diseases, and weeds were controlled using soybean-registered products as per manufacturer's indications. All areas were monitored before and after first application and products reapplied as needed. The crop managements and water irrigation were also similar between the light-supplemented and the no-light-supplemented treatments.

\subsection{Treatments and Experimental Investigation}

The pivot where the present study was implemented has ten spams and a radius of about 571 meters. In the four internal pivot spams (33.5 ha), a light supplementation system including full-spectrum light-emitting diode (LED) boards were installed. The main RGB spectral bands were about $59 \%$ red, $33 \%$ green and $8 \%$ blue. A continuous light range of approximately $40 \mathrm{~m}$ wide by $230 \mathrm{~m}$ long was projected below the extension of the four internal pivot spams.

Each LED board has a power varying between 50 and 200 watts (W). About $600 \mathrm{~W} \mathrm{~h}^{-1} \mathrm{ha}^{-1}$ were consumed during the light supplementation process. The LED boards were positioned about 3 meters above the plant canopy and distributed to ensure equally distributed light power regardless of the different moving speeds of the various pivot spams. The luminous flux per unit area (lux) at the soybean canopy level was about 30 lx. The light system used to supplement the soybean crop is presented in Figure 1. 


\section{Macrothink}
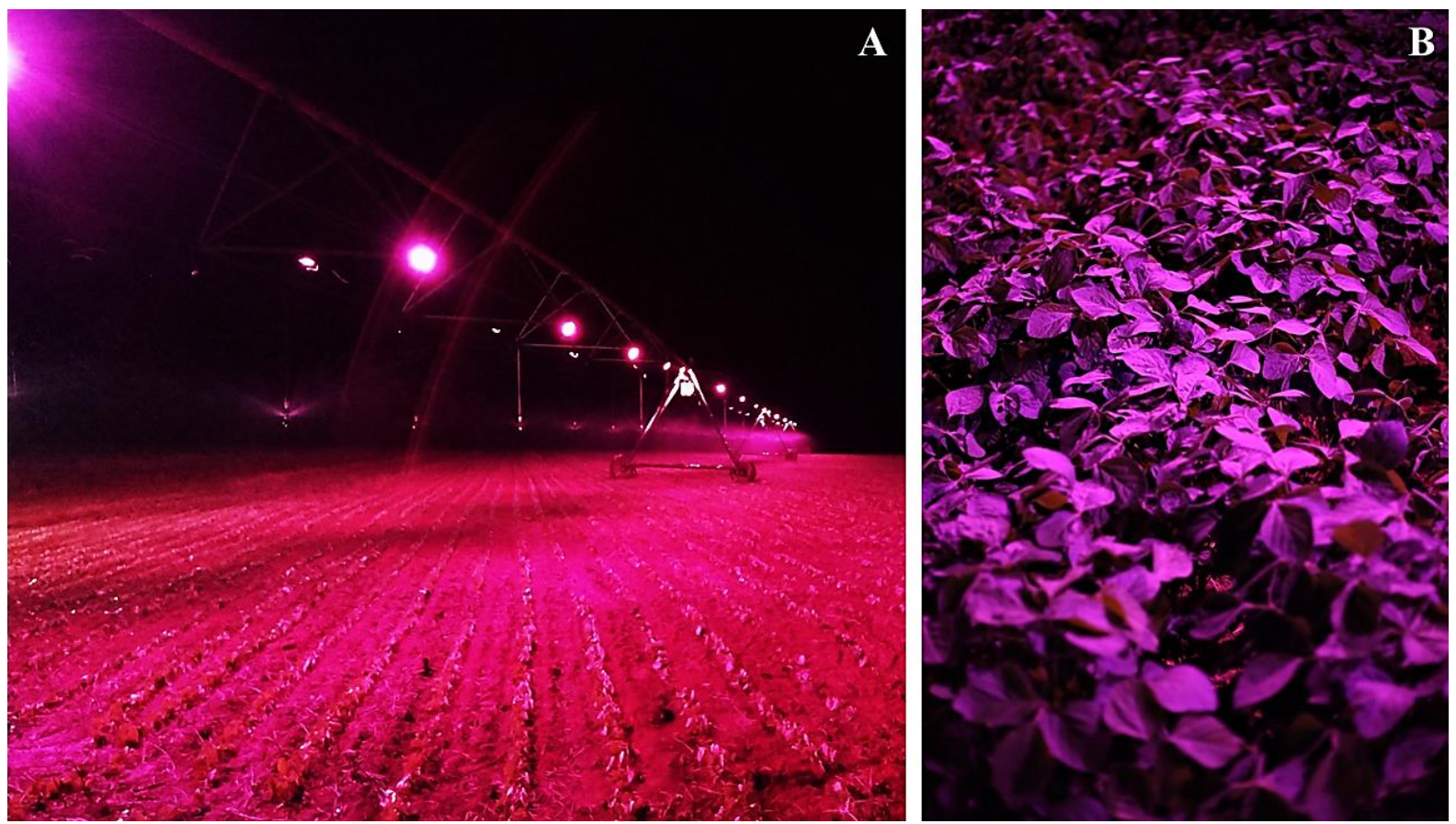

Figure 1. Light and water irrigation system (A) used to light-supplement soybean crop at night (B) and very cloud days

The light system was turned on every night (after complete sunset) and on very cloudy days. Approximately 480 hours of light supplementation was applied to the whole area during the soybean crop cycle. Since the pivot completes a full turn over the cropping area in 12.8 hours (a circular routine), each plant received about 40 hours of light supplementation during its cycle.

The light supplementation started at the V3-V4 (third-fourth trifoliate leaf fully expanded) and ended at the R5-R6 (beginning-full seed) soybean phenological stage. The six external pivot spams (69.5 ha) received no light supplementation.

Between the first and second pivot towers (second spam), a homogeneous area of 50 by $40 \mathrm{~m}$ $\left(2,000 \mathrm{~m}^{2}\right)$ was delimited to be evaluated as the "light-supplemented" (LS) treatment. Between the eighth and ninth pivot tower (ninth spam), a homogeneous area of 50 by $40 \mathrm{~m}$ $\left(2,000 \mathrm{~m}^{2}\right)$ was delimited to be evaluated as the "no-light-supplemented" (nLS) treatment. The experimental sketch of the pivot is presented in Figure 2. 


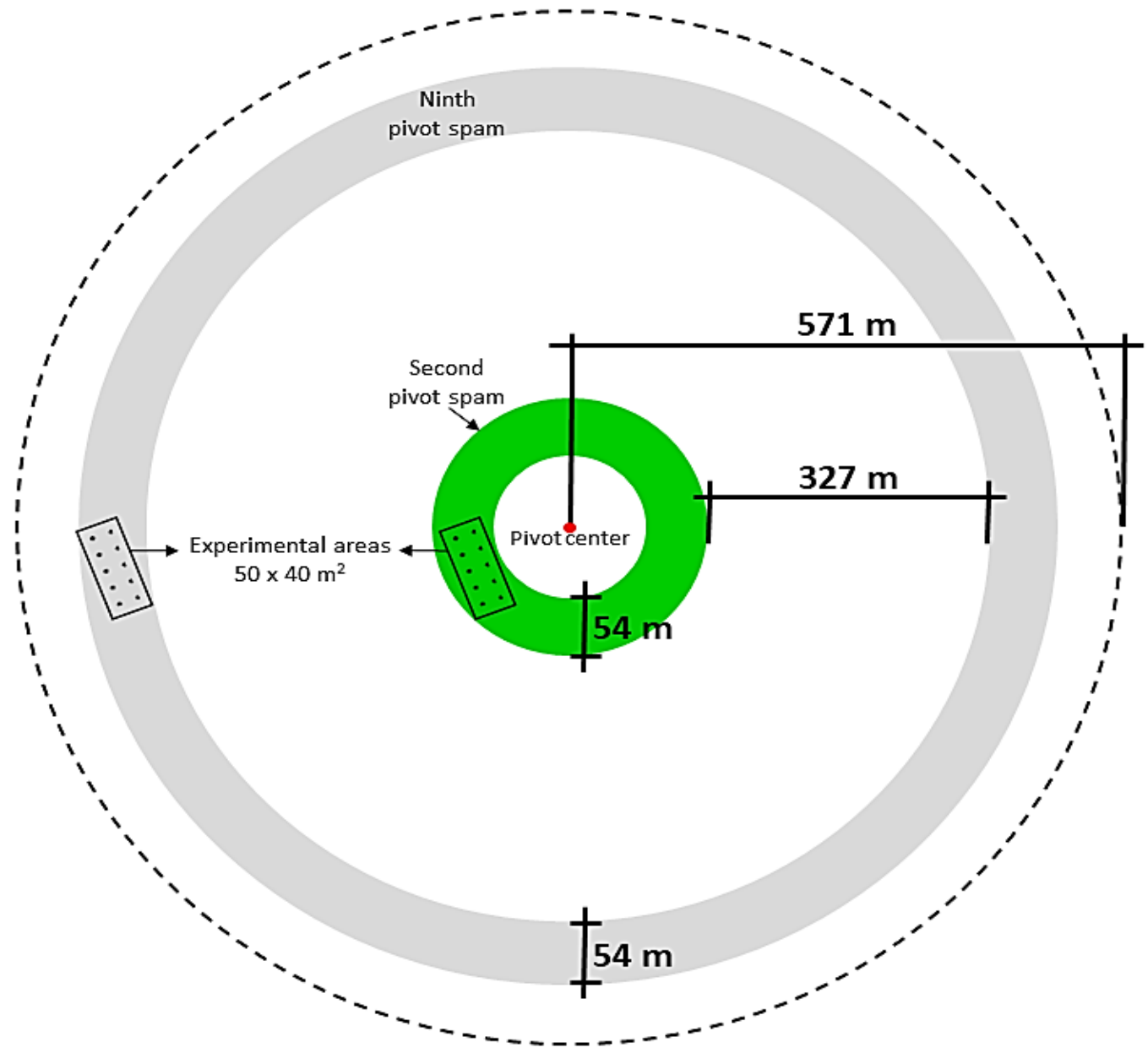

Figure 2. Experimental sketch of the irrigation pivot (102 hectares) to evaluate the effects of light supplementation on soybean crop development. Green pivot spam received light supplementation. Rectangles indicate the position of both treatments, with and without light supplementation, and dots in each rectangle indicate sampling points.

\subsection{Soybean Evaluations}

The evaluations of the internode, plant height (from soil level to the highest leaflet node), and pods per plant were done weekly from R3 (beginning pod) to R7 (beginning maturity) soybean phenological stage. During these nine weeks, evaluations were done once each week; no further assessments were possible after R7 because the plants in the nLS treatment attained physiological maturity earlier than the plants in the LS treatment. The average measurement of each variable evaluated was estimated from a representative assessment of plants at 10 sampling points in each area $\left(2,000 \mathrm{~m}^{2}\right)$ with each sampling point evaluated considered a replication.

The influence of LS or nLS on each variable was evaluated using the area under the progress curve (AUPC) of each variable (Van der Plank, 1963; Simko \& Piepho, 2012). The AUPC was calculated by the trapezoidal integration: $A U P C=\Sigma(d t i \times((Y i+Y i+d) / 2))$, where $d t i$ is the time interval between every two observations of $Y i$ and $Y i+d$. The area under the progress 
curve (AUPC) of the variables was calculated based on nine evaluations. Correlations between the AUPC of the variables evaluated were computed to determine if there was a linear relationship between them (Pearson, 1892).

The areas used for each treatment $\left(2,000 \mathrm{~m}^{2}\right)$, were harvested at 115 and 136 days after sowing for the nSL and SL, respectively. The grain productivity in each area was expressed in $\mathrm{kg} \mathrm{ha}^{-1}$.

\subsection{Statistical Analysis}

Extreme values (outliers) in the AUPC of each variable were identified using boxplot graphs of the residues (Chambers et al., 1983). When outliers were identified, the outlier was replaced using a mean value of the data set that did not include the outlier value (Burke, 2001; Kwak \& Kim, 2017). The boxplots were generated using SPSS Statistics ${ }^{\circledR}$ software, which was also used to calculate the Pearson's correlation coefficients and the basic assumptions for the analysis of variance (normality of residue distribution by Shapiro-Wilk and homogeneity of variances by Levene, both at $\mathrm{p}>0.01$ ).

The analysis of variance (ANOVA, F test) was performed after confirming its assumptions and considering a fully randomized experimental design. When significant differences were observed $(\mathrm{p}<0,05)$ in ANOVA, the AUPC of the internode number, plant height, and pods per plant were compared using Tukey's test of averages $(p<0.05)$ to distinct the treatments (LS and nLS). The ANOVA and Tukey's test analyses were performed using SISVAR ${ }^{\circledR}$ statistical program. Sigma Plot ${ }^{\circledR}$ v.12 software was used to generate the graphics.

\section{Results}

The data from the weekly evaluations of all variables (soybean internode number, the plant height, and the number of pods per soybean plant) for both treatments (LS and nLS) did not include any outliers based on the boxplots of all variables and treatments. This observation indicated that the responses were clustered around a mean with low standard error. The soybean variables and their respective standard errors during the nine weeks are presented in Figure 3.

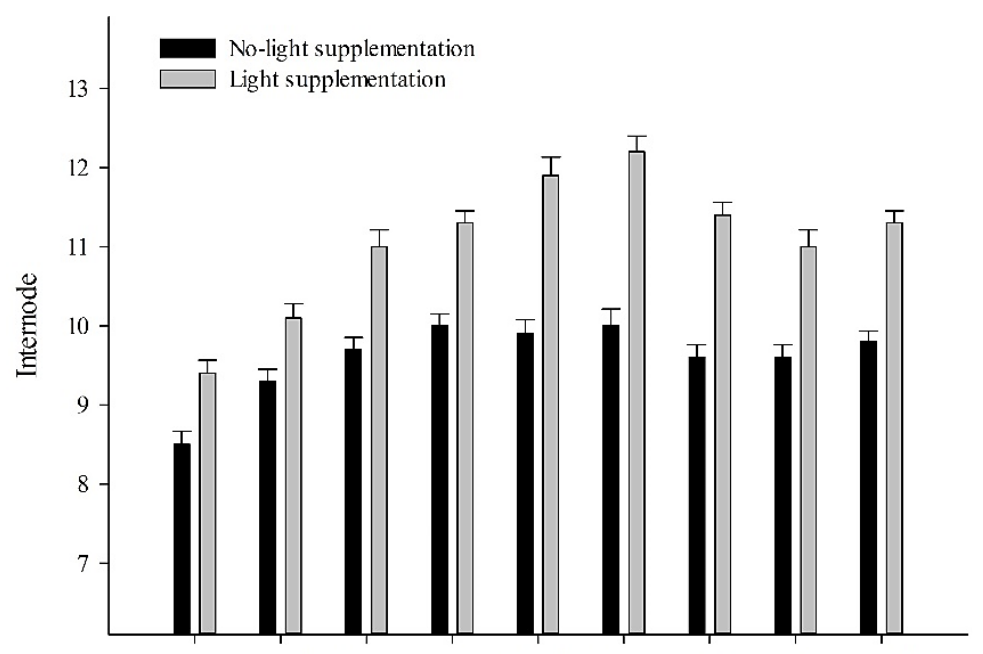



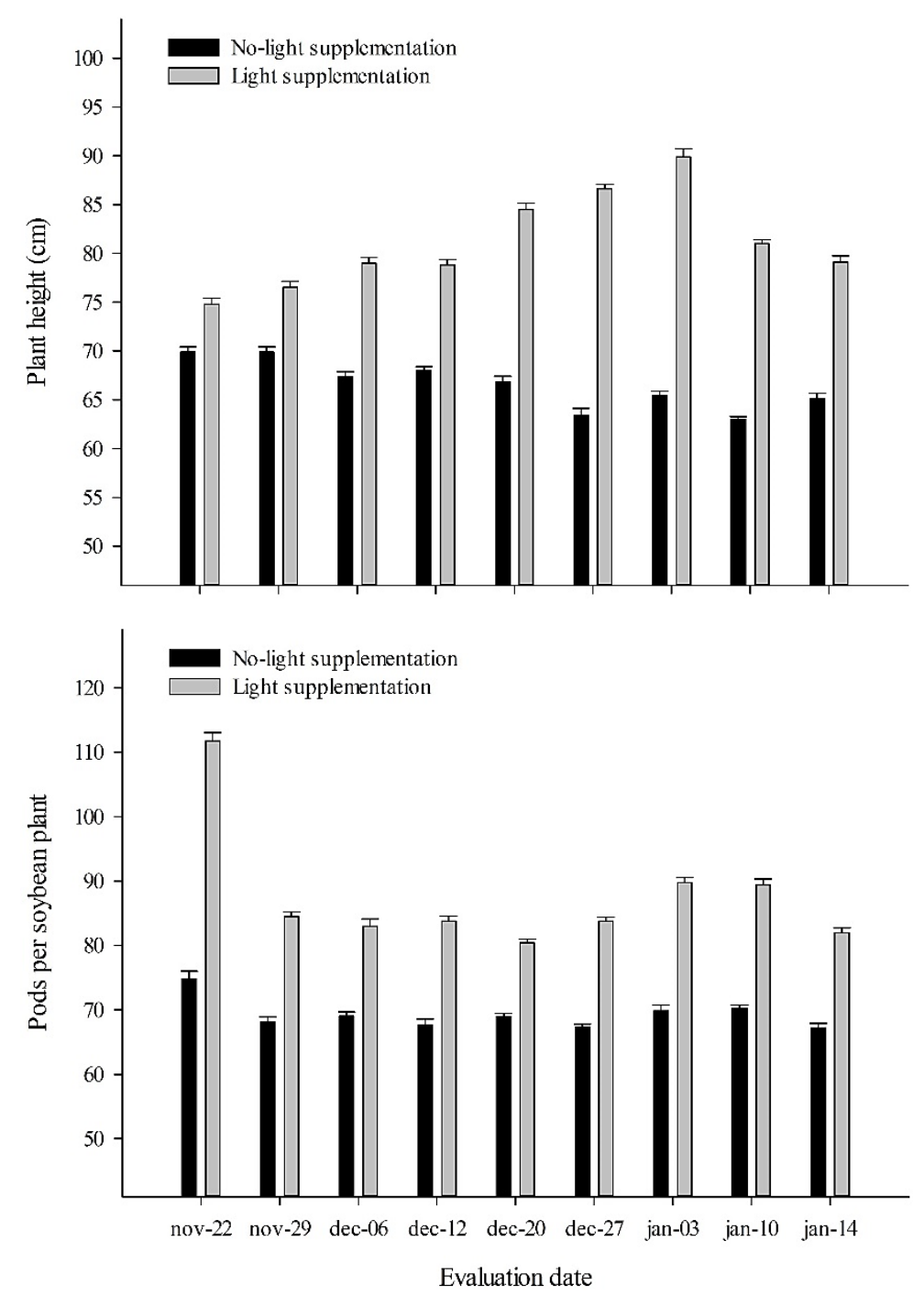

Figure 3. Internodes, height and pods per soybean plant (cultivar Desafio 8473 RSF Brasmax $\left.{ }^{\circledR}\right)$ under light supplementation and no-light supplementation. Lines over bars indicate standard error

The number of internodes per soybean plant, the plant height, and the number of pods per plant of the LS treatment were higher when compared to the no-light supplementation. These superior plant responses of the LS treatment can also be observed in Figure 4. 


\section{MInstitute Macrothink $^{\text {Int }}$}

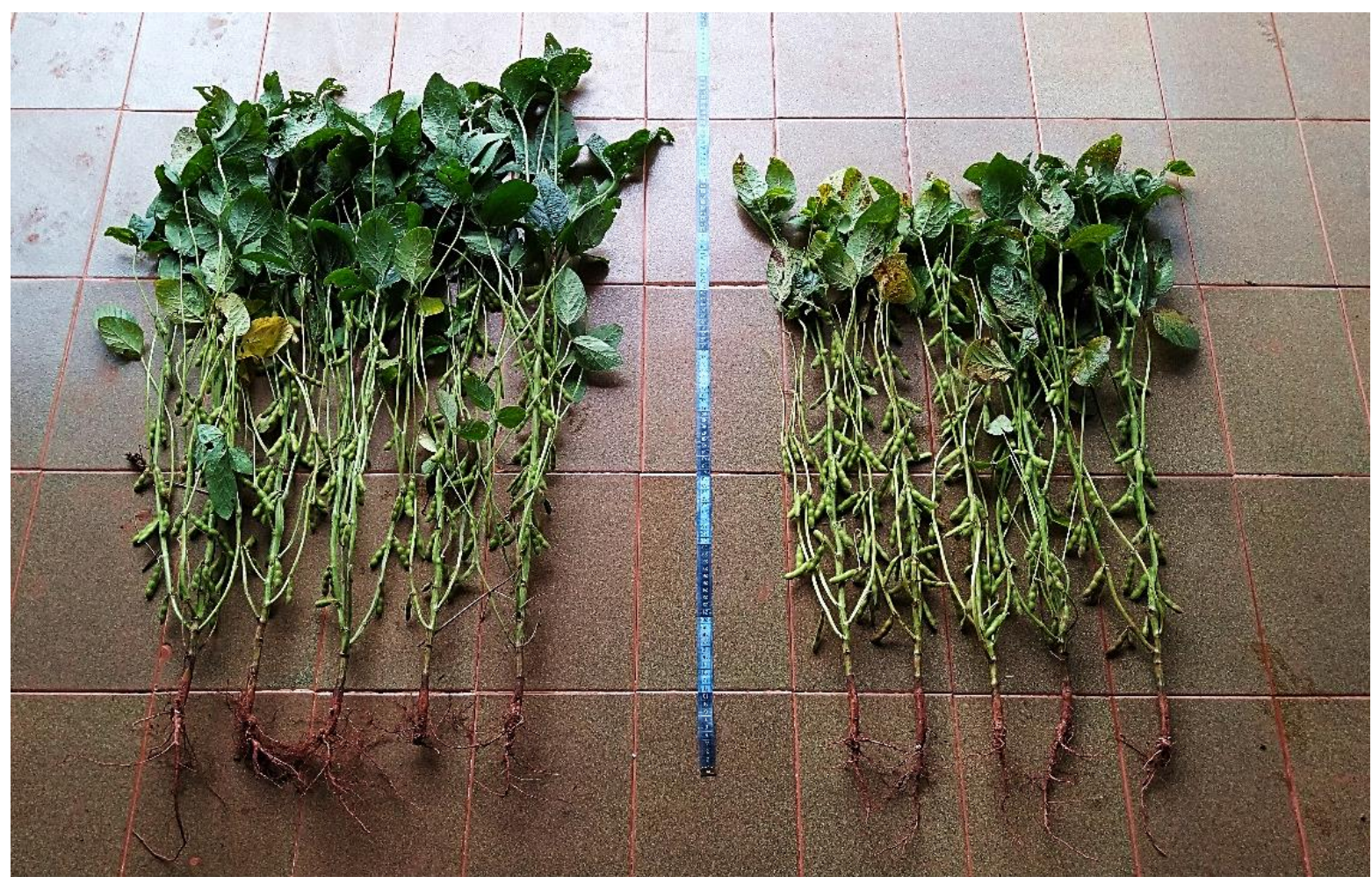

Figure 4. Soybean plants at 80 days after sown from the light supplementation (left, R5.3 soybean phenological stage) and no-light supplementation treatments (right, R6-7 soybean phenological stage). Each blue stretch in the metric tape $=0.1 \mathrm{~m}$

The analysis of variance of the AUPC and the presumptions (normality and homogeneity) are presented in Table 2.

Table 2. Analysis of variance (F test) and statistics of assumptions of the area under the progress curve of the variables soybean internode number, the plant height and the number of pods per soybean plant

\begin{tabular}{|c|c|c|c|c|}
\hline SV & $\mathrm{DF}$ & Internodes & Height & Pods per plant \\
\hline Light supplementation & 1 & $375 * *$ & $1,590 * *$ & $2,649 * *$ \\
\hline Error & 18 & & & \\
\hline $\mathrm{CV}(\%)$ & & 1.67 & 1.17 & 0.98 \\
\hline $\mathrm{KS}$ & 20 & $0.935^{+}$ & $0.985^{+}$ & $0.964^{+}$ \\
\hline $\mathrm{L}$ & $1+18$ & $1.139^{+}$ & $0.106^{+}$ & $0.262^{+}$ \\
\hline
\end{tabular}

**: significant differences at 0.01 . CV $(\%)$ : coefficient of variation. KS: Kolmogorov-Smirnov's statistics for normality of the residue distribution $(p>0.01)$. L: Levene's statistics for homogeneity of the data variances $(p>0.01) .{ }^{+}$: normality of residues (KS) or homogeneity of variances (L) fulfill.

All the AUPC data of the soybean variables (internode number, plant height, and pods per 
plant) met the ANOVA presumptions (normality of the residue distribution and homogeneity of the variances). Also, the coefficients of variation, $\mathrm{CV}(\%)$, were very low $(<2 \%)$. Thus, it was suitable to proceed with the ANOVA, which indicated significant differences $(\mathrm{p}<0.01)$ between the treatments (LS and $\mathrm{nLS}$ ).

The AUPC of the internodes per soybean plant, the plant height, and the number pods per plant of the LS treatment were 15.6, 23.3, and 25.3\% superior to that of the nLS treatment.

The Pearson's correlation computation and interpretation require that the data be normally distributed and with no outliers (extreme values) (Figueiredo Filho \& Silva Jr., 2009); these requirements were met (Table 1). All the correlations observed (Table 3) were strong correlations $(\mathrm{r}>0.9)$ according to Callegari-Jacques (2003) and attained statistical significance $(\mathrm{p}<0.01)$.

Table 3. Pearson's correlation ( $r$ ) between the AUPC of the variables studied

\begin{tabular}{lccc}
\hline & Internodes & Plant height & Pods per plant \\
\cline { 2 - 4 } Internodes & 1 & $0.962^{* *}$ & $0.970^{* *}$ \\
Plant height & & 1 & $0.990^{* *}$ \\
Pods per plant & & & 1 \\
\hline
\end{tabular}

Internodes: soybean internode number; Plant height: soybean plant height; Pods per plant: number of pods per soybean plant. **: significant differences at 0.01 .

The soybean cultivar evaluated has a cycle of approximately 17 weeks. At day 115 after sowing, the soybean plants from the $\mathrm{nLS}$ area $\left(2,000 \mathrm{~m}^{2}\right)$ were harvested; however, the harvest in the LS area was done three weeks later representing a 17.6\% longer growth cycle.

The estimated productivity of the nLS was about 4,500 kg ha-1 $\left(75 \mathrm{bags} \mathrm{ha}^{-1} ; 1 \mathrm{bag}=60 \mathrm{~kg}\right.$ ), while the LS treatment was about 7,080 kg ha ${ }^{-1}$ (118 bags ha ${ }^{-1}$. The LS grain productivity was $57.3 \%$ higher were light supplementation was applied, and $109.5 \%$ above the average of the Brazilian soybean productivity $\left(3,379 \mathrm{~kg} \mathrm{ha}^{-1}\right)(\mathrm{Conab}, 2020)$.

The average cost to produce the soybean from soil management until harvest is about 55 soybean bags per hectare. The average cost required by the light supplementation was about seven (7) bags ha ${ }^{-1}$. Thus, the profitability of the soybean traditionally produced (nLS) and the soybean produced with light supplementation were about 20 and 56 bags ha-1, respectively.

\section{Discussion}

Soybean development and flowering are majorly influenced by environmental factors such as photoperiod and temperature (Kantolic, \& Slafer, 2007; Wu et al., 2015). The extension of the soybean crop cycle by three weeks due to light supplementation also increased the plant's photosynthetic activity period. This extended cycle increased the biomass accumulation via natural daily photosynthesis; a process absent in the regular cycle of the soybean cultivar (17 weeks) where light is not supplemented. This conjunction of factors resulted in taller soybean 
plants, more internodes, more pods, and, consequently, over $57 \%$ further grain productivity.

Crop cycle extension, the number of nodes, pods, and seeds per pod, and the pod distribution within the soybean canopy are affected by extended photoperiods (Kantolic, \& Slafer, 2007; Kantolic, \& Slafer, 2001; Kantolic, \& Slafer, 2005; Kantolic et al., 2013; Nico et al., 2016). The photoperiod regulation process results in changes to the soybean development, such as the number of pods and seeds established per unit land area (Kantolic et al., 2013).

In this study, the extra yield (57.3\%) generated by an additional photosynthesis cannot solely be attributed to the hours of light supplementation provided to each soybean crop (about 40 hours). Other hypotheses should be considered; for example, photomorphogenesis (light-mediated development of the plant morphology) (Beyi, 2018; Tripathi et al., 2019), uperregulation or downregulation of phytohormones and phytochromes (Lymperopoulos et al., 2018; Tripathi et al., 2019; Faizan et al., 2020), and changes to the secondary plant metabolism (Ouzounis et al., 2015; Thoma et al., 2020).

Crop inputs, such as fertilizers, plant inoculants, and phytosanitary products, applied during the crop cycle are solely intended to maximize crop production and economic returns. Although such inputs have adverse effects on soil dynamics, these effects are often neglected (Bitew \& Alemayehu, 2017). However, the light supplementation for field crops has the potential to reduce these inputs, especially fertilizers.

The fertilizer efficiency in this study probably resulted from the significant increase in the shoots' biomass following light supplementation. An increase in the shoot biomas in turn cause a proportional increase in the root biomass. This improved root development increases the efficiency of the root nutrient absorption, thus, increasing the fertilizer efficiency (Fageria \& Moreira, 2011).

Crop production has always been intrinsically correlated nutritional, microbiological, environmental, and economic aspects that interact in a spatially sensitive manner (Joglekar et al., 2019). Consequently, response models are used to understand the consequences of such elements and their interactions. Such models can integrate valuable information about physiological processes, sowing time, irrigation blade, fertilizer doses, management of insect pests and plant diseases, and their impacts on the soil-crop-environment relationships (Sihag \& Prakash, 2019). Additionally, including climate information in such models can shed light on the relationship between crop production and weather oscillations and which in turn can be used to enhance the resilience of the global food system (food security) to unexpected climate-related shocks (Tamiru \& Fekadu, 2019; Mulungu \& Ng'Ombe, 2019; Patle et al., 2020; Heino et al., 2020).

Currently, there is an ongoing rapid increase in digitalization and integration of technologies in agriculture that is aligned with the sustainability of the ecosystems to enhance. These changes are likely to propel modern cropping to a higher level of productivity (Agriculture 5.0) (Saiz-Rubio \& Rovira-Más, 2020).

Before design cropping factors such as the genetic material to be sown, several factors should be availed. These factors include the phytosanitary management and the level of technology 
implemented other primary factors such as the nutrient availability, water supply, and light (usually from a natural source). Although availing light supplementation at the field scale is challenging to control, with affordable technologies and field resistant hardware light supplementation for crop production is possible for large commercial areas.

Currently, the world's population is about 7.88 billion people (Worldometers.org, 2021). Intensifying crop production can supply the food required by this population now and in the future. However, this does not necessarily imply hunger alleviation. Losses in crop production must also be reduced and income equity sought concurrent with the improvements in the cropping production systems (Tilman et al., 2011; Pellegrini \& Fernández, 2018).

The light supplementation technology also has a great potential to diminish the deforestation of new native areas for the purposes of crop production (Byerlee et al., 2014; Phalan et al., 2016; Koch et al., 2019). Although crop productivity can be increased with an appropriate implementation of light supplementation throughout the crop cycle, little is known about the interactions among different factors (e.g., soil, plant, climate, management), crop performance, the yield construction, and the cost-benefit relationships.

The crop production costs generated by the light supplementation system is dependent on various factors. These factors include the efficiency of the structure available (e.g., machinery, farm administration), the technology implemented (e.g., genetic materials, fertilizers) and the use precise agricultural systems (Boehlje, 2021). Other factors include irrigation system characteristics (e.g., pivot height which affects light dissipation, light supplementation on static irrigation areas), soil structuring (e.g., no physical or chemical limitation, healthy microbiota), energy supply (e.g., wiring, constancy and stability) and internet of things and crop management. Thus, the cost and profitability in the present study reflects a specific scenario of soybean production that may vary on a case to case basis. Despite this observation, light supplementation presents an opportunity to improve crop production in the same area.

There are ongoing research studies on light supplementation at field scale on many crop species with promising results. For example, researchers have observed a reduced occurrence of leaf diseases and pest insects together with an increased weed infestation in light-supplemented areas. However, focused studies are yet to confirm and understand such responses. Based on an extensive literature research, this is the first known report of light supplementation using full-spectrum LED lights to improve soybean crop production at field scale.

\section{Conclusions}

About 40 hours of light supplementation are required per plant during its crop cycle to positively affect its number of internodes, pods, plant height, and crop cycle.

Light supplementation increased soybean grain yield by $57.3 \%$ and its profitability by $180 \%$ compared to cultivation processes without artificial light supplementation.

Light supplementation to plants at field scale is a feasible and promising technique to sustainably improve crop production in the same agricultural area they are currently grown. 


\section{Acknowledgments}

Institute of Agrarian Science (ICIAG) and Institute of Geography (IG) of the Federal University of Uberlândia (UFU). Coordination of Superior Level Staff Improvement (CAPES). Fienile® Group.

\section{References}

Ali, S., Shafique, O., Mahmood, T., Hanif, M. A., Ahmed, I., \& Khan, B. A. (2018). A review about perspectives of nanotechnology in agriculture. Pakistan Journal of Agricultural Sciences, 30(2), 116-121. https://doi.org/10.17582/journal.pjar/2018/31.2.116.121

Balogh, J. M., \& Jámbor, A. (2020). The environmental impacts of agricultural trade: a systematic literature review. Sustainability, 12(3), 1-16. https://doi.org/10.3390/su12031152

Batista-Silva, W., Fonseca-Pereira, P., Martins, A. O., Zsögön, A., Nunes-Nesi, A., \& Araújo, W. L. (2020). Engineering improved photosynthesis in the era of synthetic biology. Plant Communications, 1, 100032. https://doi.org/10.1016/j.xplc.2020.100032

Beck, H. E., Zimmermann, N. E., McVicar, T. R., Vergopolan, N., Berg, A., \& Wood, E. F. (2018). Present and future Köppen-Geiger climate classification maps at 1-km resolution. Scientific Data, 5, 180214. https://doi.org/10.1038/sdata.2018.214

Besada, H., \& Sewankambo, N. (2010). Climate change in Africa: adaptation, mitigation and governance challenges. The Centre for International Governance Innovation (CIGI). Nov 2009. Accessed March 2020. https://www.cigionline.org/sites/default/files/climate_change_in_africa_3.pdf

Beyi, M. W. (2018). Plant photo morphogenesis. International Journal of Biology, Physics \& Matematics, 1(1), 104-118.

Bitew, Y., \& Alemayehu, M. (2017). Impact of crop production inputs on soil health: a review. Asian Journal of Plant Sciences, 16, 109-131. https://doi.org/10.3923/ajps.2017.109.131

Boehlje, M. (2021). The value of data/information and the payoff of precision farming. Center for Commercial Agriculture. Purdue University. February. p. 19.

Bures, S., Gavilan, M. U., \& Kotiranta, S. (2018). Artificial lighting in agriculture. Especialistes en serveis per la producció editorial. SPE3 Publisher. https://agris.fao.org/agris-search/search.do?recordID=ES2018600011

Burke, S. (2001). Missing values, outliers, robust statistics \& non-parametric methods. LC-GC Europe Online Supplement - Statistic and Data Analysis, 2, 19-24. Corpus ID: 189801314

Byerlee, D., Stevenson, J., \& Villoria, N. (2014). Does intensification slow cropland expansion or encourage deforestation? Global Food Security, 3(2), 92-98. https://doi.org/10.1016/j.gfs.2014.04.001

Callegari-Jacques, S.M. (2003). Bioestatística: princípios e aplicações. Porto Alegre: Artemed. p. 264.

Chambers, J. M., Cleveland, W. S., Kleiner, B., \& Tukey, P. A. (1983). Graphical methods for data analysis. Wadsworth and Brooks/Cole. p. 395. 
Chowdhury, D., Bharadwaj, A., \& Sehgal, V. K. (2019). Mega-environment concept in agriculture: a review. International Journal of Current Microbiology and Applied Sciences, 8(1), 2147-2152. https://doi.org/10.20546/ijcmas.2019.801.224

Companhia Nacional de Abastecimento (Conab). (2020). Acompanhamento da Safra Brasileira, $\quad 7(12)$. Accessed $\quad$ September $\quad 10, \quad 2020$. https://www.conab.gov.br/info-agro/safras/graos/boletim-da-safra-de-graos

Devlet, A. (2021). Modern agriculture and challenges. Frontiers in Life Sciences and Related Technologies, 2(1), 21-29. https://doi.org/10.51753/flsrt.856349

Empresa Brasileira de Pesquisa Agropecuária (Embrapa). (2017). Manual de métodos de análise de solo. Embrapa: Rio de Janeiro, Brazil. p. 577.

Fageria, N. K., \& Moreira, A. (2011). The role of mineral nutrition on root growth of crop plants. Advances in Agronomy, 110(1), 251-331. https://doi.org/10.1016/B978-0-12-385531-2.00004-9

Faizan, M., Faraz, A., Sami, S., Siddiqui, H., Yussuf, M., Gruzska, D., \& Hayat, S. (2020). Role of strigolactones: signalling and crosstalk with other phytohormones. Open Life Science, 15(1), 217-228. https://doi.org/10.1515/biol-2020-0022

Figueiredo Filho, D. B., \& Silva Jr., J. A. (2009). Desvendando os mistérios do coeficiente de correlação de Pearson (r). Revista Política Hoje. 18(1), 115-146.

Gómez, C., \& Izzo, L. G. (2018). Increasing efficiency of crop production with LEDs. AIMS Agriculture and Food, 3, 135-153. https://doi.org/10.3934/agrfood.2018.2.135

Goto, E. (2003). Effects of light quality on growth of crop plants under artificial lighting. Environmental Control in Biology, 41, 121-132. https://doi.org/10.2525/ecb1963.41.121

Gupta, S. D. (2017) Light emitting diodes for agriculture - smart lighting. Springer Nature Singapore. p. 334. https://doi.org/10.1007/978-981-10-5807-3

Harsimrat, K. B., \& Kaur, M. (2020). Role of plant growth regulators in improving fruit set, quality and yield of fruit crops: a review. Journal of Horticultural Science and Biotechnology. 95(2), 137-146. https://doi.org/10.1080/14620316.2019.1660591

Heino, M., Guillaume, J. H. A., Müller, C., Iizumi, T., \& Kummu, M. (2020). A multi-model analysis of teleconnected crop yield variability in a range of cropping systems. Earth System Dynamics, 11, 113-128. https://doi.org/10.5194/esd-11-113-2020

Hemming, S. (2011). Use of natural and artificial light in horticulture - interaction of plant $\begin{array}{llll}\text { and technology. Acta Horticulturae, } & \text { 907, }\end{array}$ https://doi.org/10.17660/ActaHortic.2011.907.1

Intergovernmental Panel on Climate Change (IPCC). (2014). Climate Change 2014. Synthesis Report. Contribution of Working Groups I, II and III to the Fifth Assessment Report of the Intergovernmental Panel on Climate Change - Core Writing Team, Pachauri R.K., \& Meyer, L.A. (eds.). IPCC, Geneva, Switzerland, 151 pp. https://archive.ipcc.ch/report/ar5/syr/. Access in April 25, 2020.

Joglekar, A. K. B., Wood-Sichra, U., \& Pardey, P. G. (2019). Pixelating crop production: consequences of methodological choices. PLoS ONE, 14(2), e0212281. https://doi.org/10.1371/journal.pone.0212281 
Kaiser, E., Galvis, V. C., \& Armbruster, U. (2019). Efficient photosynthesis in dynamic light environments: a chloroplast's perspective. Biochemical Journal, 476(19), 2725-2741. https://doi.org/10.1042/BCJ20190134

Kantolic, A. G., \& Slafer, G. A. (2001). Photoperiod sensitivity after flowering and seed number determination in indeterminate soybean cultivars. Field Crops Research, 72(2), 109-118. https://doi.org/10.1016/s0378-4290(01)00168-x

Kantolic, A. G., \& Slafer, G. A. (2005). Reproductive development and yield components in indeterminate soybean as affected by post-flowering photoperiod. Field Crops Research, 93, 212-222. https://doi.org/10.1016/j.fcr.2004.10.001

Kantolic, A. G., \& Slafer, G. A. (2007). Development and seed number in indeterminate soybean as affected by timing and duration of exposure to long photoperiods after flowering. Annals of Botany, 99, 925-933. https://doi.org/10.1093/aob/mcm033

Kantolic, A. G., Peralta, G. E., \& Slafer, G. A. (2013). Seed number responses to extended photoperiod and shading during reproductive stages in indeterminate soybean. European Journal of Agronomy, 51, 91-100. https://doi.org/10.1016/j.eja.2013.07.006

Koch, N., zu Ermgassen, E. K. H. J., Wehkamp, J., Oliveira Filho, F. J. B., \& Schwerhoff, G. (2019). Agricultural productivity and forest conservation: evidence from the Brazilian Amazon. American Journal of Agricultural Economics, 101(3), 919-940. https://doi.org/10.1093/ajae/aay110

Kwak, S. K., \& Kim, J. H. (2017). Statistical data preparation: management of missing values and outliers. Korean Journal of Anesthesiology, 70(4), 407-411. https://doi.org/10.4097/kjae.2017.70.4.407

Leakey, A. D. B., Ferguson, J. N., Pignon, C. P., Wu, A., Jin, Z., Hammer, G. L., \& Lobell, D. B. (2019). Water use efficiency as a constraint and target for improving the resilience and productivity of C3 and C4 crops. Annual Review of Plant Biology, 70(1), 781-808. https://doi.org/10.1146/annurev-arplant-042817-040305

Lowenberg-DeBoer, J., \& Erickson, B. (2019). Setting the record straight on precision agriculture adoption. Agronomy Journal, 111, 1552-1569. https://doi.org/10.2134/agronj2018.12.0779

Lymperopoulos, P., Msanne, J., \& Rabara, R. (2018). Phytochrome and phytohormones: Working in tandem for plant growth and development. Frontiers in Plant Science, 9, 1-14. https://doi.org/10.3389/fpls.2018.01037

Mulungu, K., \& Ng'Ombe, J. N. (2019). Climate change impacts on sustainable maize production in Sub-Saharan Africa: a review. IntechOpen, 1-11. https://doi.org/10.5772/intechopen.90033

Nico, M., Mantese, A. I., Miralles, D. J., \& Kantolic, A. G. (2016). Soybean fruit development and set at the node level under combined photoperiod and radiation conditions. Journal of Experimental Botany, 67(1), 365-377. https://doi.org/10.1093/jxb/erv475

Nowicka, B., Ciura, J., Szymańska, R., \& Kruk, J. (2018). Improving photosynthesis, plant productivity and abiotic stress tolerance - current trends and future perspectives. Journal of Plant Physiology, 231, 415-433. https://doi.org/10.1016/j.jplph.2018.10.022

Orr, D. J., Pereira, A. M., Pereira P. F., Pereira-Lima, Í. A., Zsögön, A., \& Araújo, W. L. 
(2017). Engineering photosynthesis: progress and perspectives. F1000Research, 6, 1891. https://doi.org/10.12688/f1000research.12181.1

Ouzounis, T., Rosenqvist, E., \& Ottosen, C. O. (2015). Spectral effects of artificial light on plant physiology and secondary metabolism: A review. HortScience, 50(8), 1128-1135. https://doi.org/10.21273/HORTSCI.50.8.1128

Pandey, S., Shrivastava, A., Vijay, R., \& Bhandari, S. (2019). A review on smart irrigation and crop prediction system. International Conference on Sustainable Computing in Science, Technology \& Management (SUSCOM-2019). Jun 14. Accessed March 3, 2020. https://papers.ssrn.com/sol3/papers.cfm?abstract_id=3358108

Patle, G. T., Kumar, M., \& Khanna, M. (2020). Climate-smart water technologies for sustainable agriculture: a review. Journal of Water and Climate Change. https://doi.org/10.2166/wcc.2019.257

Pearson, K. (1892). The grammar of science. Londres, RU: Walter Scott. p. 493.

Pellegrini, P., \& Fernández, R. J. (2018). Crop intensification, land use, and on-farm energy-use efficiency during the worldwide spread of the green revolution. Proceedings of the National Academy of Sciences USA, 115(10), 2335-2340. https://doi.org/10.1073/pnas.1717072115

Phalan, B., Green, R., Dicks, L., Dotta, G., Feniuk, C., Lamb, A., Strassburg, B. B., Williams, W. D., Ermgassen, E. K. H. J., \& Balmford, A. (2016). How can higher-yield farming help to spare nature? Science, 351, 450-451. https://doi.org/10.1126/science.aad0055

Raman R. (2017). The impact of genetically modified (GM). crops in modern agriculture: A review. GM Crop Food, 8(4), 195-208. https://doi.org/10.1080/21645698.2017.1413522

Roberts, D. P., \& Mattoo, A. K. (2019). Sustainable crop production systems and human nutrition. Frontiers in Sustainable Food $\quad$ Systems, $3, \quad 72$. https://doi.org/10.3389/fsufs.2019.00072

Saiz-Rubio, V., \& Rovira-Más, F. (2020). From smart farming towards Agriculture 5.0: a review on crop data management. Agronomy, 10(2), 207. https://doi.org/10.3390/agronomy 10020207

Sihag, J., \& Prakash, D. A. (2019). Review: importance of various modeling techniques in agriculture/crop production. In Sihag, J.; Prakash, D. Soft computing: theories and applications. pp. 699-707. https://doi.org/10.1007/978-981-13-0589-4_66

Silva, J. M., Montaldo, Y. C., Almeida, A. C. P. S., Dalbon, D. A., Acevedo, J. P. M., Santos, T. M. C., \& Lima, G. S. A. (2021). Rhizospheric fungi to plant growth promotion: a review. Journal of Agricultural Studies, 9(1), 412-425. https://doi.org/10.5296/jas.v9i1.18321

Simkin, A. J., López-Calcagno, P. E., \& Raines, C. A. (2019). Feeding the world: improving photosynthetic efficiency for sustainable crop production. Journal of Experimental Botany, 70(4), 1119-1140. https://doi.org/10.1093/jxb/ery445

Simko, I., \& Piepho, H. P. (2012). The area under the disease progress stairs: calculation, advantage, and application. Analytical and Theoretical Plant Pathology, 102, 381-389. https://doi.org/10.1094/PHYTO-07-11-0216

Singer, S. D., Soolanayakanahally, R. Y., Foroud, N. A., \& Kroebel, R. (2020). 
Biotechnological strategies for improved photosynthesis in a future of elevated atmospheric $\mathrm{CO}_{2}$. Planta, 251, 24. https://doi.org/10.1007/s00425-019-03301-4

Singh, N., \& Singh, A. N. (2020). Odysseys of agriculture sensors: Current challenges and forthcoming prospects. Computers and Electronics in Agriculture, 171, 1-14. https://doi.org/10.1016/j.compag.2020.105328

Small, C. C., \& Degenhardt, D. (2018). Plant growth regulators for enhancing revegetation success in reclamation: a review. Ecological engineering, 118, 43-51. https://doi.org/10.1016/j.ecoleng.2018.04.010

Tamiru, L., \& Fekadu, H. (2019). Effects of climate change variability on agricultural productivity. International Journal of Environmental Sciences \& Natural Resources, 17(1), 018555953. https://doi.org/10.19080/IJESNR.2019.17.555953

Thoma, F., Somborn-Schulz, A., Schlehuber, D., Keuter, V., \& Deerberg, G. (2020). Effects of light on secondary metabolites in selected leafy greens: a review. Frontiers in Plant Science, 11, 497. https://doi.org/10.3389/fpls.2020.00497

Tilman, D., Balzer, C., Hill, J., \& Befort, B. L. (2011). Global food demand and the sustainable intensification of agriculture. Proceedings of the National Academy of Sciences USA. 108, 20260-20264. https://doi.org/10.1073/pnas.1116437108

Toungos, M. D. (2018). Plant growth substances in crop production: a review. International Journal on Agricultural and Biological Research. 6(3), 1-8.

Tripathi, S., Hoang, Q. T. N., Han, Y. J., \& Kim, J. I. (2019). Regulation of photomorphogenic development by plant phytochromes. International Journal of Molecular Sciences. 20, 6165. https://doi.org/10.3390/ijms20246165

Van der Plank, J. E. (1963). Plant diseases: epidemics and control. Academic Press, New York. p. 349.

Van Iersel, M. W. (2017). Optimizing LED lighting in controlled environment agriculture. In Gupta, S.D. (Ed.) Light emitting diodes for agriculture: Smart Lighting, (pp. 59-80). Springer Nature, Singapore Pte Ltd.

Worldometers.org. Actual world population. Accessed July 17, 2021. https://www.worldometers.info/br/

Wu, T. T., Li, J. Y., Wu, C. X., Sun, S., Mao, T. T., Jiang, B. J., Hou, W. S., \& Han, T. F. (2015). Analysis of the independent- and interactive-photo-thermal effects on soybean flowering. Journal of Integrative Plant Biology. 14(4), 622-632. https://doi.org/10.1016/S2095-3119(14)60856-X

\section{Copyrights}

The author(s) retain all copyrights and grant first publication rights to the journal.

This is an open-access article distributed under the terms and conditions of the Creative Commons Attribution license (http://creativecommons.org/licenses/by/4.0/). 